\title{
Residues of plant protection products in grey partridge eggs in French cereal ecosystems
}

\author{
Elisabeth Bro $^{1} \cdot$ James Devillers $^{2} \cdot$ Florian Millot $^{1} \cdot$ Anouk Decors $^{1}$
}

Received: 28 September 2015 / Accepted: 11 January 2016 / Published online: 3 February 2016

(C) The Author(s) 2016. This article is published with open access at Springerlink.com

\begin{abstract}
The contamination of the eggs of farmland birds by currently used plant protection products (PPPs) is poorly documented despite a potential to adversely impact their breeding performance. In this context, 139 eggs of 52 grey partridge Perdix perdix clutches, collected on 12 intensively cultivated farmlands in France in 2010-2011, were analysed. Given the great diversity of PPPs applied on agricultural fields, we used exploratory GC/MS-MS and LC/MS-MS screenings measuring ca. 500 compounds. The limit of quantification was $0.01 \mathrm{mg} / \mathrm{kg}$, a statutory reference. A total of 15 different compounds were detected in 24 clutches. Nine of them have been used by farmers to protect crops against fungi (difenoconazole, tebuconazole, cyproconazole, fenpropidin and prochloraz), insects (lambda-cyhalothrin and thiamethoxam/clothianidin) and weeds (bromoxynil and diflufenican). Some old PPPs were also detected (fipronil(+sulfone), $\mathrm{HCH}(\alpha, \beta, \delta$ isomers), diphenylamine, heptachlor(+epoxyde), DDT( (2isomers)), as well as $\operatorname{PCBs}(153,180)$. Concentrations ranged between $<0.01$ and $0.05 \mathrm{mg} / \mathrm{kg}$ but reached 0.067 (thiamethoxam/clothianidin), 0.11 (heptachlor + epoxyde) and 0.34 (fenpropidin) $\mathrm{mg} / \mathrm{kg}$ in some cases. These results testify an actual exposure of females and/or their eggs to PPPs in operational conditions, as well as to
\end{abstract}

Responsible editor: Philippe Garrigues

Electronic supplementary material The online version of this article (doi:10.1007/s11356-016-6093-7) contains supplementary material, which is available to authorized users.

Elisabeth Broelisabeth.bro@oncfs.gouv.fr

1 National Game and Wildlife Institute (ONCFS), Research Department, Saint Benoist, 78610 Auffargis, France

2 Centre de Traitement de l'Information Scientifique, 3 chemin de la Gravière, 69140 Rillieux La Pape, France organochlorine pollutants or their residues, banned in France since several years if not several decades, that persistently contaminate the environment.

Routes of exposure, probability to detect a contamination in the eggs, and effects on egg/embryo characteristics are discussed with regard to the scientific literature.

Keywords Bird $\cdot$ Egg $\cdot$ Exposure route $\cdot$ Farmland $\cdot$ Residue analysis $\cdot$ Pesticide

\section{Introduction}

The most recent European Red List reviewing the conservation status of all European species reports that only $48 \%$ of bird species associated with agricultural ecosystems are classified within the status "least concern"- to be compared to $80 \%$ for all bird species (BirdLife International 2015a). The rate of biodiversity loss in farmlands is therefore still worrying, despite target 3 of the European Union strategic plan for biodiversity aims to "increase the contribution of agriculture and forestry to maintaining and enhancing biodiversity" by 2020 (European Commission 2011).

Farmland bird species have suffered from severe historical declines (European Bird Census Council 2015). It is well established that intensification of farming practices and associated changes in habitat were the main drivers of this decline, through direct and indirect effects (e.g., Benton et al. 2002; Chamberlain et al. 2000; Donald et al. 2001, 2006; Evans 2004; Robinson and Sutherland 2002; and references therein). Farmland birds continue to decline today (Comolet-Tirman et al. 2015; European Bird Census Council 2015), as a result of various threats including illegal hunting, climate change and severe weather, interaction with invasive species, changes in land-use practices (intensification of agriculture and land abandonment), 
pollution, etc. (BirdLife International 2015a). Farming practices and habitat changes are, however, still major drivers of bird decline (BirdLife 2015a; Eglington and Pearce-Higgins 2012; Stoate et al. 2009). Recent works suggest that the agricultural use of actual plant protection products (PPPs) still contributes to the ongoing decline of avian populations (Bro et al. 2010; Geiger et al. 2010; Hallmann et al. 2014; Mineau and Whiteside 2013; van der Sluijs et al. 2015; van Lexmond et al. 2015). Indeed, although bird ecotoxicology has been poorly documented compared to other taxa (Köhler and Triebskorn 2013), it is admitted from field surveys, correlative data analysis and laboratory experiments that some active substances (ASs) can affect the survival of birds and their breeding success through different mechanisms.

Adverse effects may occur indirectly through a reduction in food abundance (weeds, seeds and invertebrates) resulting in a poor breeding success (e.g., Boatman et al. 2004; Hart et al. 2006; Rands 1985). They may also occur directly by oral, air or contact contamination. Intoxication can then lead to death or to sublethal behavioural or immune disorders that can favour the death (cf. Garg et al. 2004; Lopez-Antia et al. 2013, 2015; Millot et al. 2015; and ref therein), as well as reproductive disorders such as anomalies in courtship behaviour (Fernie et al. 2003; Ottinger et al. 2008); anatomical anomalies of gonads (Bauer 1985); decrease in chick production rate through reduced clutch size, clutch abandonment, reduced fertility, teratogenicity or other effects such as eggshell thinning (Fernie et al. 2003; Kamata et al. 2010; Kitulagodage et al. 2011; Lopez-Antia et al. 2015; Maci and Arias 1987; Mendenhall et al. 1983; Mineau 2005); reduced chick survival and poor chick condition (Bhaskar et al. 2012; Kitulagodage et al. 2011; Lopez-Antia et al. 2015; Mineau 2005; Nitu et al. 2012; Uggini et al. 2012). Intergenerational effects are also observed (Bauer 1985; Fernie et al. 2003).

However, such effects are documented for only a small number of ASs that are currently used. In addition, most of the above very interesting cited works are lab studies. They provide useful information but no firm conclusion that such effects actually occur in the "real world". Additional field works are therefore needed to consolidate the results. The first requirement is the proof of a real contamination of the birds and their eggs in operational conditions. There is a large body of scientific literature on this subject, but few studies deal with current pesticide ASs and with herbivorous-granivorousinsectivorous farmland birds. In this context, this study contributes to fill this gap of knowledge by providing field data for a typical farmland bird, the grey partridge (Perdix perdix). The ecology of this ground nesting bird makes it a suitable focal species: (i) it mainly lays its clutches in crops, with a preference for winter cereals (Bro et al. 2013) and (ii) it feeds on a variety of items including sprouts, grains and seeds of both cultivated and weed plants, and invertebrates. In addition, the species is of conservation concern in several European states (UK, Sotherton et al. 2014; France-“Centre" area, CSRPN 2013; Switzerland, Keller et al. 2010; etc.) due to its ongoing population decline and/or range contraction (BirdLife International 2015b). The management of this game species benefitted from a large amount of research throughout the world (e.g., review of Sotherton et al. 2014 for UK; e.g., Bro et al. 2000a, b, 2001, 2004, 2013 for France), but relatively little attention was paid to field ecotoxicology so far.

\section{Methods}

\section{Egg collection and storage}

We collected failed eggs from hatched, destroyed and deserted clutches of radiotagged grey partridge females (Bro et al. 2015). They were put in quail egg boxes and stored in the dark at $-20{ }^{\circ} \mathrm{C}$.

\section{Examination of egg and embryo status}

Intact failed eggs were opened in the lab to examine their content. They were classified as "infertile" (no germinal disc observed, which includes embryos at development stage $\leq 1-$ 2 days; Bro et al. 2013; McCabe and Hawkins 1946), "dead embryo" and "undetermined" (when we were not certain of the status of the egg, such as in the case of rotten eggs). We looked by eye for macroscopical deformities of embryos $\geq 15$ days old (bill, skull, eye or leg defects; Ludwig et al. 1996). Eggshell thickness was measured to the nearest $0.001 \mathrm{~mm}$ by the same investigator using a digital micrometer (IP65 0-25 mm, Mitutoyo, Japan). Measures were done at the equator region after a careful separation of the inner membranes.

\section{Residue analysis}

\section{Quality assurance}

Residue analyses were performed by Phytocontrol (Nîmes, France). The laboratory is accredited by the French Committee of Accreditation (COFRAC) for the research and quantification of pesticides in foodstuffs (no. 1-1904, COFRAC 2010). It works in compliance with the international standard ISO/IEC 17025 and according to the LAB GTA 26 99-2 program. In addition, the laboratory is certified ISO 14001 by the French Agency of Normalisation (AFNOR).

The methods were validated using several criteria: recovery rates, repeatability, reproducibility, specificity and linearity (SANCO/12571/2013, European Commission / Health \& Consumer Protection Directorate 2013). 


\section{Multi-residue analyses}

Sample preparation Samples were prepared using a QuEChERS protocol which couples an extraction method of pesticides using a solvent and a clean-up method using purification salts adapted to the matrix and to the substances. We used QuEChERS no. NF EN 15662.

Extraction Ten grams of the whole egg was mixed with $10 \mathrm{~mL}$ of pure water and $10 \mathrm{~mL}$ of acetonitrile. Acetonitrile was used as the extraction solvent because of its effectiveness to remove polar components such as sugars, lipids, organic acids, sterols, proteins, pigments and excess water. Salts $(4 \mathrm{~g}$ $\mathrm{MgSO}_{4}, 1 \mathrm{~g} \mathrm{NaCl}$, citrate buffer at $\left.\mathrm{pH}=5-5.5\right)$ were added, and the mixture was vigorously shaken for $10 \mathrm{~min}$ and then centrifuged at $15^{\circ} \mathrm{C}$ for $5 \mathrm{~min}$ at $3000 \times g$ to separate the solid and liquid phases.

Purification An aliquot of the supernatant $(5 \mathrm{~mL})$ was purified using a dispersive solid phase extraction (d-SPE) involving salts containing $900 \mathrm{mg}$ of anhydrous $\mathrm{MgSO}_{4}, 300 \mathrm{mg}$ of PSA and $300 \mathrm{mg}$ of $\mathrm{C} 18$. After a vigorous shaking for $10 \mathrm{~min}$, mixtures were centrifuged at $15^{\circ} \mathrm{C}$ for $5 \mathrm{~min}$ at $3000 \times g$.

The supernatant $(8 \mathrm{~mL})$ was split into two fractions of $4 \mathrm{~mL}$ and evaporated under a nitrogen stream. One fraction was acidified with $5 \%$ formic acid solution and redissolved in $0.2 \mathrm{~mL}$ of acetonitrile for GC/MS-MS analysis. The second fraction was redissolved in $0.2 \mathrm{~mL}$ of mobile phase $(0.1 \%$ acetic acid in water/acetonitrile, 50/50 $v / v$ ) for LC/MS-MS analysis.

Identification and quantification Five microliters and $2 \mu \mathrm{L}$ were injected in LC and GC, respectively. Compounds were identified and quantified with a triple quadrupole tandem (QqQ) mass spectrometry (electrospray source, pos and neg). The use of QqQ analyzers improves the sensitivity and the selectivity of the analysis. Each compound was characterised by its retention time, a quantitation transition, a confirming transition and the ratio between the signals of these transitions. For linearity, $R$ values ranged between 70 and $120 \%$.

Residues of ca. 500 compounds were measured using both LC/MS-MS and GC/MS-MS screenings (Online Resource 1). Compounds were ASs and/or their isomers and/or their metabolites. The recovery yields of all compounds varied between 70 and $120 \%$, with a coefficient of variation of $20 \%$.

Of the ASs we listed as used by the farmers in our 12 study sites in spring and summer 2010-2011, 85.5\% were measured (Online Resource 2, Bro et al. 2015). The remaining ASs were not measured either because they were not proposed in routine by the laboratory or because they needed costly specific analyses. Their inclusion would have severely exceeded our budget for pesticide residue analysis.
Intrumentation For GC/MS-MS, analyses were carried out using GC/MS-MS Scion (Bruker). Quantification was performed with a workstation from Bruker. For LC/MS-MS, analyses were carried out using a Shimadzu 8040. Quantification was performed with Labsolution from Shimadzu.

Quality control In each batch of samples, two controls were included: a reagent blank consisting of a vial containing only solvent extract and an internal laboratory quality control (QC, concentration $100 \mathrm{ppb}$ ) consisting of a spiked matrix with a mix of pesticides. The batch analyses were considered valid when the values of the analytes in the QC were within a range of $70-120 \%$ of the theoretical value.

Analytical performance The analytical methods used allowed to reach a limit of quantification (LoQ) of $0.01 \mathrm{mg} /$ $\mathrm{kg}$ for almost all compounds-LoQ was lower for fipronil(+ sulfone): $0.005 \mathrm{mg} / \mathrm{kg}$, and higher for flonicamide(+TNFA + TNFG) and TNFG: $0.05 \mathrm{mg} / \mathrm{kg}$ (Online Resource 1). The limit of detection (LoD) was approximatively half of LoQ. The value of $0.01 \mathrm{mg} / \mathrm{kg}$ is the default value for maximum residue levels (MRLs) ${ }^{1}$ when no specific MRL is set out for a given product (Regulation (EC) No. 396/2005, article 18 1.(b)).

\section{Selection of clutches and eggs for analyses}

We analysed intact failed eggs. This is a common practice because this sampling is non-invasive. The drawback is the bias in the sample, which limits the cause to effect and other quantitative interpretation of the results (see Discussion), but it does not weaken an exploratory analysis of egg contamination. Another common practice is to analyse the first or the second egg laid (e.g., Eng et al. 2014) to limit the variability in the results. However, in our case, this was neither possible because we did not know the laying sequence (the location of a nest is only known once the clutch is completed and incubation is initiated), nor desirable. Indeed, as much as 18 eggs - sometimes more - can be laid within ca. 20-30 days. Thus, all of them are not likely to be exposed to an AS following its application (see Bro et al. 2015). As a consequence, a non-positive result obtained on one egg cannot be extrapolated to the whole clutch. The analysis of several eggs is then required to maximise the probability to detect a contamination. In this context, we sometimes pooled a few eggs in a same sample, trying to find the best compromise between the risk of a potential dilution effect on the one hand and the funds available on the other hand.

Clutches and eggs were selected following three "strategies":

\footnotetext{
${ }^{1}$ See Online Resource 4
} 
1. Eggs displaying worst cases with regards to several endpoints (eggshell thickness, embryo deformity),

2. Failed eggs of successful clutches with lowest egg hatching rates,

3. Eggs of clutches potentially exposed to specific ASs (ASs that have been commonly used but that would need further consideration with regards to risk assessment for avian reproduction (first-tier toxicity-exposure ratio $\left(\mathrm{TER}_{1 \mathrm{t}}\right)<5$; Bro et al. 2015; EFSA 2009)).

Hatched eggs were not analysed so far both for financial and analytical reasons. Only the calcareous eggshells and chorionic membranes are available. The quantity is likely to be insufficient to allow residue analyses, and this matrix may not be the best one to detect compounds. Additional tests are therefore required.

\section{Sample size}

We performed residue analyses on 52 clutches collected on 12 sites located in intensively cultivated farmlands in northcentral France (Bro et al. 2015; Millot et al. 2015). These clutches corresponded to 645 eggs laid, of which $38.8 \%$ hatched. One hundred thirty-nine eggs were analysed, representing $21.6 \%$ of the total number of eggs laid and $35.2 \%$ of failed eggs. The 139 eggs were constituted into 73 samples of one to four eggs. Clutches were analyzed for pesticide residues through one to three samples and one to eight eggs (Table 1).

\section{Potential exposure}

We considered that a female (and then her eggs) was potentially exposed to an AS if the area where it was radiotracked during the pre-laying, egg-laying or incubation periods overlapped with treated fields (see Bro et al. 2015 for methodological details). When a compound was detected in a clutch, we provided data (date, crop, dose of $\mathrm{AS}(\mathrm{s})$ ) about the corresponding treatment(s) of the field(s) frequented by the females and their eggs. We calculated the amount of the AS applied on the field ( $\mathrm{g} / \mathrm{ha})$ by multiplying the dose (1/ha) applied by the farmers and the concentration of the AS in the trade formulation $(\mathrm{mg} / \mathrm{l}$ or $\mathrm{g} / \mathrm{l})$. The former was known from a farmer survey ${ }^{2}$ (Bro et al. 2015), the latter from information retrieval in the E-PHY database managed by the French Ministry of Agriculture (http://ephy.agriculture.gouv.fr/).

\footnotetext{
${ }^{2}$ Field data "checked" on E-PHY
}

\section{Results}

\section{Clutch contamination}

We detected contaminants in 24 out of the 52 analysed clutches, i.e., $46.2 \%$ (Table 1). Globally, few compounds were detected compared to what one could have expected on the basis of potential exposure (Online Resources 2 and 3). A total of 15 different compounds were found, of which nine ASs are currently used by farmers to protect crops. The detected substances were azole (difenoconazole, tebuconazole, cyproconazole, prochloraz) or amine (fenpropidin) fungicides, pyrethroid and neonicotinoid insecticides (lambdacyhalothrin and thiamethoxam/clothianidin, respectively) and herbicides (bromoxynil-hydroxybenzonitrile and diflufenican - pyridinecarboxamide). The other compounds were fipronil(+sulfone), $\mathrm{HCH}(\alpha, \beta, \delta$ isomers $)$, diphenylamine, heptachlor(+epoxyde), DDT( $\Sigma$ isomers $)$ and $\operatorname{PCBs}(153,180)$.

We detected one compound in $70.8 \%$ of the 24 contaminated clutches, two compounds in $12.5 \%$ and more complex mixtures (three to five compounds) in $16.7 \%$. In one clutch, we detected two compounds that were combined in a trade coformulation (tebuconazole and fenpropidin; cf. Online Resource 3: clutch 2011-45-586-1).

\section{Concentrations}

A compound was detected but not quantified in 14 cases (Table 1). When concentrations were quantified, they were generally within one to four/five orders of magnitude of the LoQ. Higher concentrations were quantified in three cases: $0.067 \mathrm{mg} / \mathrm{kg}$ of thiamethoxam/clothianidin, $0.11 \mathrm{mg} / \mathrm{kg}$ of heptachlor(+epoxyde) and $0.34 \mathrm{mg} / \mathrm{kg}$ of fenpropidin (Table 1).

\section{Contamination and exposure}

In eight cases, we could associate the contamination of the clutch to a potential exposure of the female during egg formation and/or egg laying (Online Resource 3). The fungicide fenpropidin was frequently detected when "expected" (three clutches out of four potentially exposed, Online Resource 2), but this was not observed for the other ASs. The dose applied on the field often corresponded to a low volume compared to the approved maximum dose.

In nine other cases, contamination could not be associated with a potential exposure of the female identified using the method of Bro et al. (2015), but the AS has been used in the study site of the corresponding year. Data are provided in the last column ("other uses in the site") in Online Resource 3. In other cases, the compounds that were detected were not listed 


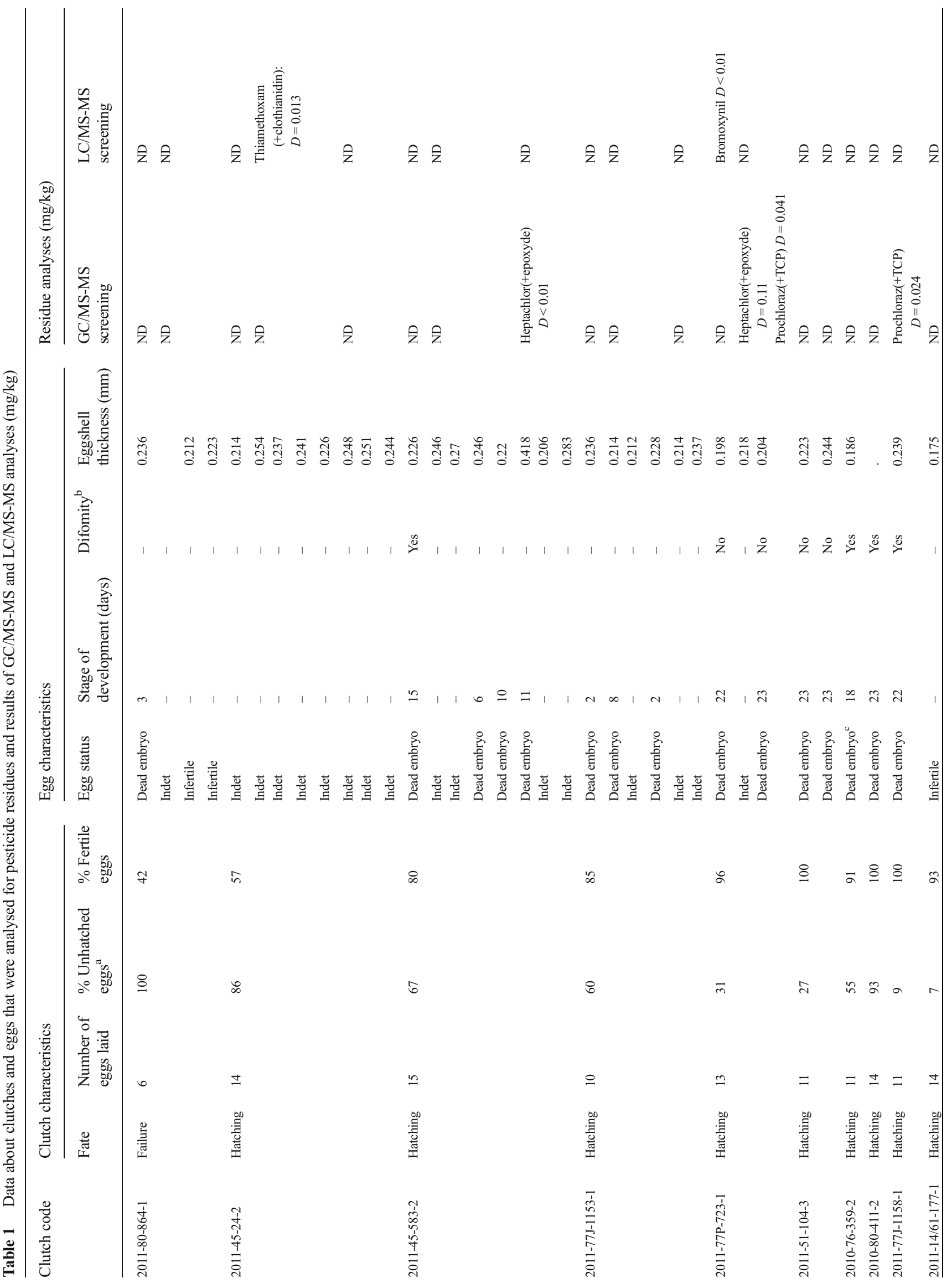




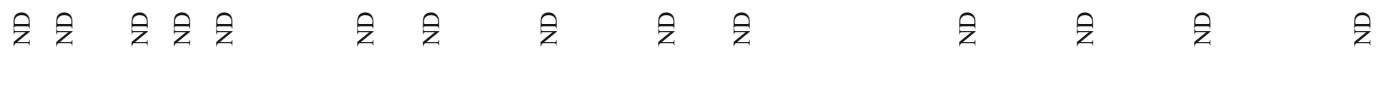

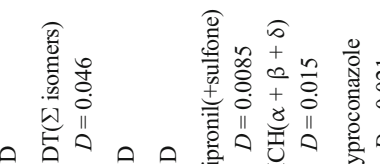

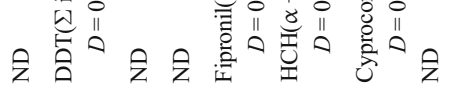

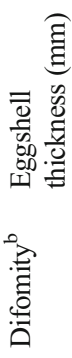

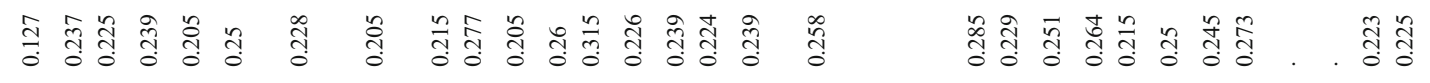

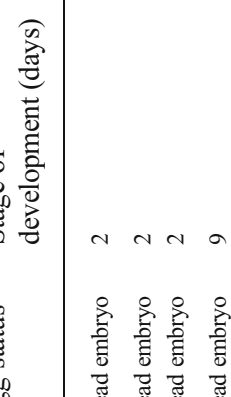

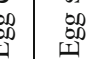

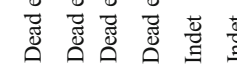

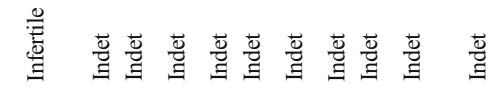

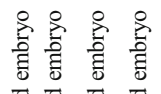

$=m \simeq \cong, \quad \simeq \simeq \cong \cong$

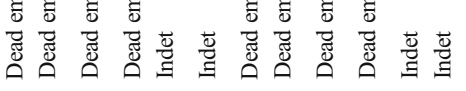

䓪

焉 $\stackrel{\infty}{\infty}$

$$
\infty \quad
$$

$\infty$

$\curvearrowleft$

๙

む

苞

苛

$1 \quad n \pi$

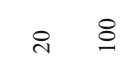

$\stackrel{\infty}{\sim}$

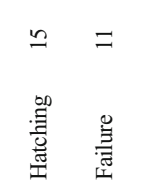

$\infty$

ㅇ

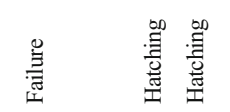

玨

营

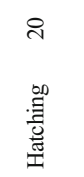

$\stackrel{\infty}{=}$

曾

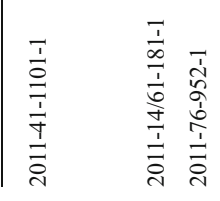

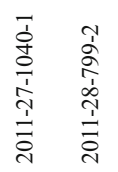

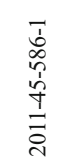

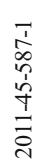

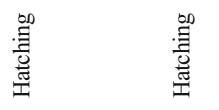




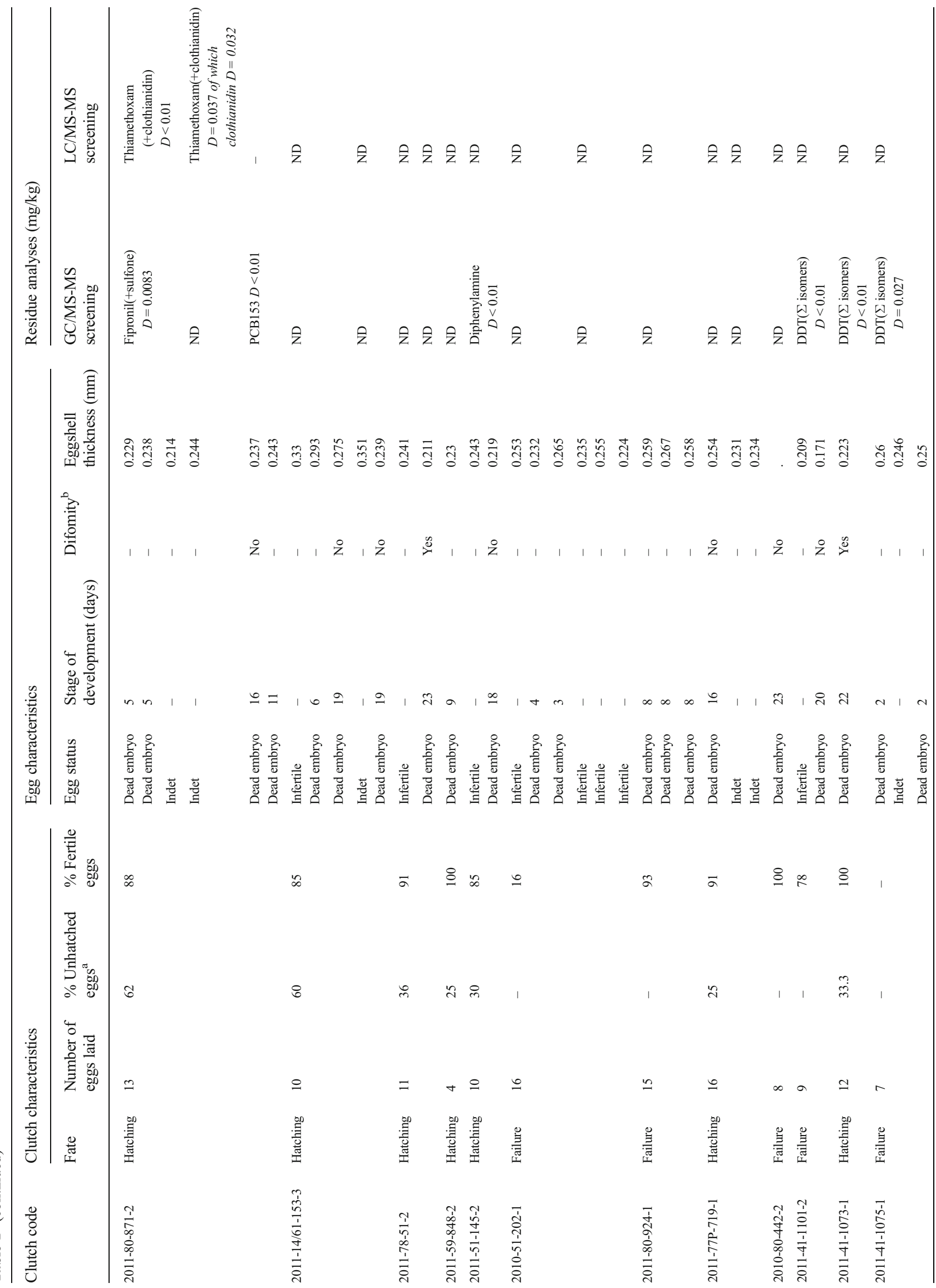




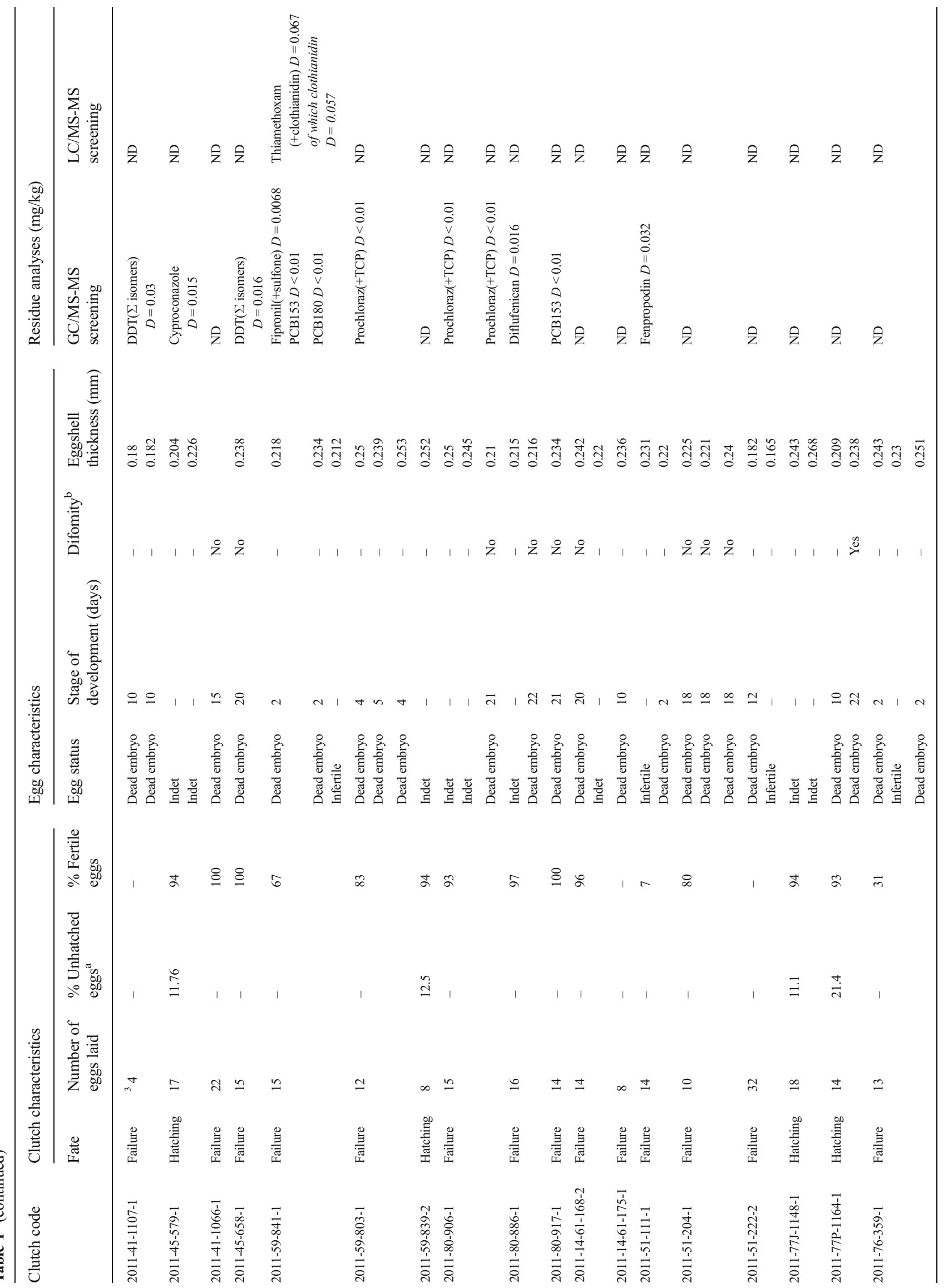


as ASs used by the farmers (and not as a pesticide in case of PCBs).

\section{Discussion}

\section{Contamination of eggs by current active substances}

Contamination of farmland birds by the PPPs currently used in agriculture is poorly documented in situ, with some exceptions such as raptor species (see Gómez-Ramírez et al. 2014). In this context, this study provides some field data on a typical medium-sized omnivorous farmland bird, the grey partridge. It reports the contamination of some eggs by some current ASs. Such result is a first stone in the foundation of further investigations of unintentional effects of PPPs on non-target wildlife in cultivated landscapes. The second main contribution of this work is to provide field references of concentration of some ASs in eggs, and data about the treatments of the field(s) frequented by the females and/or where their eggs were laid. However, it remains difficult in the state of the art to relate concentrations in eggs to exposure doses given the gaps of knowledge (identification and quantification of the different routes of exposure) and of data (transfer characteristics in eggs) in birds. In spite of this, our results would be useful to plan lab experiments with realistic in ovo injections (e.g., Blus and Henny 1997; Dunachie and Fletcher 1970; Fischer 2005).

We detected nine ASs out of the hundred to which eggs have been potentially exposed to (Bro et al. 2015, Online Resource 2). It would have been be quite interesting to correlate the detection of ASs to a series of factors such as their physico-chemical properties, their environmental fate, their metabolism in birds (see data compiled in Online Resource 4), as well as the associated treatments (crop, usage, time and type of application, dose applied, window of exposure, etc.; see data in Online Resource 3). Unfortunately, available data of contamination are not sufficient so far to provide a reliable analysis. In particular, absence of detection and detection of mixtures should be consolidated by a higher sample size.

Contamination by thiamethoxam and clothianidin should be discussed with regards to the current regulatory ban of some neonicotinoids in some countries. These ASs were detected as thiamethoxam/clothianidin in three clutches laid in 2011 in three different geographical sites (Online Resource 3). This contamination has probably been detected as a result of exposure to thiamethoxam. Indeed, it was used on these three sites between March and May, when sowing beet, maize or pea seeds - authorised uses in 2011 (Online Resource 3). Two females frequented one or two fields of maize in April and one female a field of canning peas in May. Thus, exposure is therefore highly credible knowing the diet and the habitat use of the species. These potential exposures were not 
identified by Bro et al. (2015) because they considered a 15day period before the laying date of the first egg (this corresponds to the main phase of yolk formation in the domestic hen) to determine potential exposure. Sowing of coated seeds occurred before that time.

Clothianidin was identified as the main residue in two samples (Online Resource 3). This is compatible with an exposure to thiamethoxam since clothianidin is a metabolite of thiamethoxam metabolism in the domestic hen (EFSA 2014). Clothianidin is maybe a residue also found in eggs (this is not mentioned in the report) given that it is the major residue found in the liver. More quantitative data would be welcome to interpret more deeply our results. However, we cannot exclude an exposure to clothianidin given that this AS was authorised in France on maize from 1 April to 31 July 2011, as in-furrow application of pellets (ANSES 2011; DRIAAF 2011). Parent compound is reported to account for $20 \%$ of the radioactivity of residues in eggs following an exposure of laying hens to clothianidin (EFSA 2014). This scenario is however not the most probable according to our field data.

\section{Routes of contamination}

Four routes of contamination were possible: (1) a direct exposure of the eggs when the pesticides were sprayed, (2) a direct exposure of the eggs through the contaminated vegetation, (3) a direct exposure of the eggs through the contaminated feathers of the females and (4) a maternal transfer to the eggs (through diet, preening and/or inhalation). They are not mutually exclusive. All were considered in the method that was proposed by Bro et al. (2015) to identify and quantify potential exposure.

Direct exposure is a likely phenomenon both because most ASs applied in the fields during the breeding season are sprayed (Millot et al. 2015) and because the grey partridge is a terrestrial bird that mainly lives and nests in crops (Bro et al. 2013). However, whether direct exposure is an important route of egg contamination is an open question. The behaviour of grey partridge females may prevent direct exposure from spraying as well as favour it from treated vegetation, depending upon the relative dates of treatments and laying. Indeed, laying females only remain on their nests during a few hours per day to lay (Birkan and Jacob 1988), and they cover their eggs with plant material found around the nest when they leave it (McCabe and Hawkins 1946). A direct exposure of the clutch when the crop where it was laid has been treated may have occurred in four cases out of the eight contaminated clutches with a potential exposure identified with the method used by Bro et al. (2015).

Maternal exposure is likely to be an important route of exposure given (1) the timing of pesticide use (mainly during egg formation, Bro et al. 2015), (2) the diet of the species and (3) the biochemical origin of egg content (lipovitellin and phosvitin, some yolk lipoproteins, are exclusively synthetised by the liver of the laying hen (Sauveur and de Reviers 1988); thus, lipophilic ASs may be included in fatty content). In addition, the metabolism studies performed in laying hens indeed demonstrate a residue transfer to the eggs for many ASs (Online Resource 4, EFSA reasoned opinions). Exposure through inhalation cannot be excluded given that some of the ASs are volatile (Online Resource 4) and are detected in the air (Marlière 2009).

\section{Which level of contamination at the population scale?}

We detected compounds in slightly less than half of the clutches we analysed, and the ASs were generally quantified at low concentrations, i.e., close to the limit of quantification. One of the two issues now is to know whether it rather reflects a low or a high level of contamination at the population scale. At the current stage of the work, it is difficult to draw a conclusion. Indeed, egg sample is biased toward unhatched eggs. This may overestimate the detection of contaminations if contaminations reduce egg hatching rate, as well as underestimate it if contaminations only impact hatchling conditions (e.g., Kitulagodage et al. 2011). Laying order may also have influenced the probability to detect an exposure to an AS, but this aspect is not known with our field data.

The probability to detect contaminations in situ taking into account the different mechanisms of losses and transfer should also be considered to interpret the results. We did not find data about transfer of ASs into egg content through eggshell and membranes for the ASs under interest in case of a direct exposure despite immersion experiments have been performed (Dunachie and Fletcher 1966, 1967). Transfer rate is increased when a fat-soluble AS is associated to oil vehicle (Hoffman and Albers 1984). If egg contamination results from a maternal effect, we need to look at the metabolism of the AS in birds. Detailed data exist on poultry. Experiments on laying hens administered (chronically or not) with radiolabelled ASs provide information on the excretion rate and on the kinetics of the ASs, as well as on the distribution of residues in organs, tissues and eggs. Partial data can be found in public reports and databases (Online Resource 4). Given that domestic hens and grey partridges are both galliform species, we assume that hen data are representative of our species. Data on metabolism in laying hens indicate that the (at least some) ASs are rapidly and mainly excreted via the urine and/or the faeces. Only small amounts of residues are transferred to the eggs. In the light of these pieces of information, we expect to only detect a maternal contamination as a "weak signal" given the probability to capture such event. This issue has been already highlighted as inherent to field conditions (Quintaine et al. in press), and abnormality frequency may be more informative than deviations from means (Egea-Serrano et al. 2012). Under 
this hypothesis, and taking into account any prior degradation in the environment (metabolism in plants, phytolysis, etc.), our results might indicate a more global non-target pesticide exposure of farmland birds.

\section{Effects on breeding performance}

The second key issue is to relate residues in eggs to effects on the individuals (health concern) and in fine on the population dynamics (population management concern). Correlating actual exposure (presence and concentration of ASs) to the characteristics of individual eggs (fate, eggshell thickness) and embryos (stage of development when death occurred, deformity) would have required to perform a separate analysis for each egg and to analyse simultaneously control eggs. Other endpoints such as the oxidative stress may also be valuable additive information.

Some ASs detected in partridge eggs may influence, under certain exposure conditions, the fecundity, the fertility and the development of embryos of some bird species (Lopez-Antia et al. 2013; Rivière et al. 1985) or are suspected to have endocrine disrupting properties (e.g., EFSA 2010, 2011; Saxena et al. 2015). However, whether such effects actually occur in the field remains an open question. This issue is still a current challenge in avian ecotoxicology. It is all the more complex to be documented that a series of other causes may contribute to variations in clutch size (Mourão et al. 2010), fertility rate (Bramwell 2002) and embryonic mortality rate (Mourão et al. 2010; Nakage et al. 2003; Wilson et al. 2003). In this context, field (Bishop et al. 2000), semi-field (Johnston et al. 1996) and/ or lab (Lopez-Antia et al. 2013, 2015; Kitulagodage et al. 2011) experimental studies are required to control potential confounding factors and provide conclusive results.

\section{Contaminations by other pollutants}

We detected in partridge eggs some compounds (DDT/ isomers, $\mathrm{PCB} /$ congeners, heptachlor, $\mathrm{HCH} /$ isomers) that are listed on annex A or B of the Stockholm convention on persistent organic pollutants (POPs). These chemicals are widely distributed and persistent in the environment, they bioaccumulate through the food web and are toxic to humans and wildlife. As such, they still receive special attention from researchers. As a consequence and contrarily to current pesticide ASs, a large body of literature is devoted to these compounds in wild birds (e.g., Fernie et al. 2003; Fry 1995; Gómez-Ramírez et al. 2014; Hoffman et al. 2002; Meador 1996). These compounds are still detected in many bird species throughout the world (e.g., Augspurger et al. 2008wood duck in USA; Clark et al. 2009-peregrine falcon in USA; Eng et al. 2014-starling in Canada; GomezRamirez et al. 2012; Martínez-López et al. 2007-
Eurasian eagle owl, booted eagle and goshawk in Spain; Fliedner et al. 2012-herring gull in Germany; Gao et al. 2009-six species of aquatic birds (gull, tern, plover, common coot), ring-necked pheasant, mallard and swan in China; Kocagöz et al. 2014-gulls, coot and heron in Turkey; Malik et al. 2011-cattle egret in Pakistan). Our results provide however new data since little is known about their occurrence in freeliving galliform birds. The concentrations are however quite lower than the ones currently quantified in other species/countries and are not likely to reduce the breeding success of the grey partridge.

Soil particles ingested with grit or soil residues absorbed by plants may be the exposure route for compounds such as $\mathrm{HCH}$ (Orton et al. 2013), fipronil or neonicotinoids (Bonmatin et al. 2015) that are stored in French soils. The spot of contamination by DDT/isomers is less obvious, and only hypotheses can be proposed. In some raptor studies, it is suggested that the recent increase of DDE concentrations in eggs are due to a local use of dicofol (in Gómez-Ramírez et al. 2014; Wiemeyer et al. 1989, 2001), an organochlorine acaricide manufactured from DDT used to protect vegetables and fruits (JMPR - Joint FAO/WHO Meeting on Pesticide Residues 2011). International regulations limit impurities in technical dicofol, but accidents in pesticide refinement are possible. Such an origin in our study may be plausible given that (i) DDT/isomers were detected in clutches of partridges living in a site where strawberries, legumes and wine are produced and (ii) its use as an acaricide on strawberries, beans and grapes was banned in France in late March 2010 (EPHY database, accessed September 2015). Although this AS was not listed in the course of our study, we cannot exclude that it has been used by some farmers that did not participate to the work (see Bro et al. 2015; Millot et al. 2015).

\section{Conclusion}

This work provides evidence of the contamination of a farmland galliform bird by some pesticide ASs. The characteristics of rapid and high excretion rate of ASs and their low transfer rate to tissues, organs and eggs measured in worst-case situations do not fully prevent contamination of non-target organisms in the real world. This result is congruent with risk assessment estimates of some ASs (higher tier TER lower or close to 5, EFSA 2009). However, the effects of the contamination we detected on egg characteristics and egg fate cannot be inferred from our data. It is known from lab studies that exposure to some ASs, of which chemicals suspected to have endocrine disruptor properties, during embryonic development may have reproductive consequences, but whether such effects occur in the field remains an open question. Conclusions will only be drawn from experiments simulating operational conditions 
of use. However, before planning experiments, exposure in field conditions should be better documented. Provided that funds were available, partridge failed eggs might be a noninvasive monitoring tool of contamination of farmland birds by PPPs. Indeed, hunters are solicited to collect clutches deserted by partridges following disturbance, for instance by crop harvesting, and to make the eggs incubated by bantam hens or artificially in specific centres. A proportion of eggs could be analysed. Such dedicated surveys are already operational for monitoring wildlife poisoning incidents (e.g., SAGIR in France-http://www.oncfs.gouv.fr/ Reseau-SAGIR-ru105, the Wildlife Incident Investigation Scheme in UK-http://www.pesticides.gov.uk/guidance/ industries/pesticides/topics/reducing-environmentalimpact/wildlife) or monitoring some contaminants in some raptor species and their eggs (reviewed by Gómez-Ramírez et al. 2014). Such a wide-scale scheme could be implemented for farmland birds and PPPs. It would be highly valuable as a surveillance tool of pesticide contamination of wildlife as a complement of more focused studies (Quintaine et al. in press; Lopez-Antia et al. 2013, 2015).

\begin{abstract}
Acknowledgments The field survey ("PeGASE" study) was carried out by the National Game and Wildlife Institute (ONCFS) and several hunter associations $(14,27,28,41,45,51,59,62,76,77$, 80, Ile-deFrance and Champagne-Ardenne). The work was conducted in association with field technicians of hunter associations. We are grateful to the landowners and the hunters for giving us permission to work on their land. A. Mesbah (ONCFS and Fertil'avi and University of Tours), J.-P. Brillard (Fertil'avi) and C. Bressac (University of Tours) contributed to embryologic analyses. We thank the laboratory Phytocontrol for help in writing the Method section, F. Reitz (ONCFS) for helpful comments on a first version of the manuscript and two anonymous referees whose constructive criticism helped improve the paper.
\end{abstract}

\section{Compliance with ethical standards}

Ethical statement This study was conducted in accordance with the principles and specific guidelines of the French legislation for animal welfare and wildlife regulations (authorisations AP no. 2009-014 and no. 2010-013). No animal was killed for the purpose of this study. Eggs were collected after hatching or failure of the clutches; thus, residue analyses were only conducted on failed eggs.

Funding The field study was funded by participants and Europe (European Regional Development Fund - no. 32962 and no. 32936), France (Fonds National d'Aménagement et de Développement du Territoireno. 32956; Conseils Généraux 27, 41 and 76-no. 850050068 and no. Arr/B954), hunter associations (Fédération Nationale des Chasseurs, Fondation François Sommer, Club de l'Epagneul Breton, Société Canine d'Ile-de-France), Agence Services and Paiement Limousin and Vermillon.

This research is supported by the research program "Assessing and reducing environmental risks from plant protection products" funded by the French Ministries in charge of Ecology and Agriculture, with a financial support from the National Water and Aquatic Environment Institute (ONEMA). Funds issue from the fees on diffuse pollution. Convention ONEMA-ONCFS no. 2012/XX; assigned funds no. RA/12/785.

Conflict of interest The authors declare that they have no conflict of interest.
Open Access This article is distributed under the terms of the Creative Commons Attribution 4.0 International License (http:// creativecommons.org/licenses/by/4.0/), which permits unrestricted use, distribution, and reproduction in any medium, provided you give appropriate credit to the original author(s) and the source, provide a link to the Creative Commons license, and indicate if changes were made.

\section{References}

ANSES (2011) Avis de l'Agence nationale de sécurité sanitaire de l'alimentation, de l'environnement et du travail relatif à une demande de mise sur le marché pour la préparation CHEYENNE, à base de clothianidine, de la société PHILAGRO France. Anses dossier n²010-1397 - CHEYENNE, 25p. https://www.anses.fr/fr/ system/files/DPR2010ha1397.pdf (In French)

Augspurger TP, Echols KR, Peterman PH, May TW, Orazio CE, Tillitt DE, Di Giulio RT (2008) Accumulation of environmental contaminants in wood duck (Aix sponsa) eggs, with emphasis on polychlorinated dibenzo-p-dioxins and polychlorinated dibenzofurans. Arch Environ Contam Toxicol 55:670-682. doi:10.1007/ s00244-008-9199-1

Bauer CA (1985) Effects of paraquat on reproduction and growth in northern bobwhite. J Wildl Manag 49:1066-1073. http://www. jstor.org/stable/3801397

Benton TG, Bryant DM, Cole L, Crick HQP (2002) Linking agricultural practice to insect and bird populations: a historical study over three decades. J Appl Ecol 39:673-687. http://www.jstor.org/stable/ 827176

Bhaskar N, Shahani L, Taparia N, Bhatnagar P (2012) Effect of deltamethrin containing formulation on developing chick embryo: morphological and skeletal changes. Intern J Tox Pharmacol Res 13:81-87

BirdLife International (2015a) European red list of birds. Luxembourg: office for official publications of the European Communities. http:// www.birdlife.org/datazone/userfiles/file/Species/erlob/ EuropeanRedListOfBirds_June2015.pdf. Connected 3 August 2015

BirdLife International (2015b) European red list of birds. Perdix perdix (Grey Partridge). Luxembourg: Office for official publications of the European Communities. http://www.birdlife.org/datazone/userfiles/ file/Species/erlob/summarypdfs/22678911_perdix_perdix.pdf. Connected 3rd August 2015

Birkan M, Jacob M (1988) La perdrix grise. Hatier, France. (in French)

Bishop CA, Collins B, Mineau P, Burgess NM, Read WF, Risley C (2000) Reproduction of cavity-nesting birds in pesticide-sprayed apple orchards in southern Ontario, Canada, 1988-1994. Environ Tox Chem 19:588-599. doi:10.1002/etc.5620190310

Blus LJ, Henny CJ (1997) Field studies on pesticides and birds: unexpected and unique relations. Ecol Appl 7:1125-1132. http://www. jstor.org/stable/2641201

Boatman ND, Brickle NW, Hart JD, Milsom TP, Morris AJ, Murray AWA, Murray KA, Robertson PA (2004) Evidence for the indirect effects of pesticides on farmland birds. Ibis 146:131-143. doi:10. 1111/j.1474-919X.2004.00347.x

Bonmatin J-M, Giorio C, Girolami V, Goulson D, Kreutzweiser D, Krupke C, Liess M, Long E, Marzaro M, Mitchell E, Noome D, Simon-Delso N, Tapparo A (2015) Environmental fate and exposure; neonicotinoids and fipronil. Environ Sci Pollut Res 22:35-67. doi:10.1007/s11356-014-3332-7

Bramwell RK (2002) Fertility and embryonic mortality in breeders. Avian Advice 4:1-4. http://www.avianadvice.uark.edu/AA\%20PDFs/ avian_advice_4.2.pdf

Bro E, Reitz F, Clobert J, Mayot P (2000a) Nest-site selection of grey partridge (Perdix perdix) on agricultural lands in north-central France. Game Wildl Sci 17:1-16. http://www.oncfs.gouv.fr/IMG/ 
file/oiseaux/galliformes/plaine/PG_publi/perdrix $\% 20$ grise $\%$ 20Bro\%202000a\%20-\%20GWS\%2017.pdf

Bro E, Sarrazin F, Clobert J, Reitz F (2000b) Demography and the decline of the grey partridge Perdix perdix in France. J Appl Ecol 37:432448. doi:10.1046/j.1365-2664.2000.00511.x

Bro E, Clobert J, Reitz F, Migot P, Massot M (2001) Diagnosing the environmental causes of the decline in grey partridge survival in France. Ibis 143:120-132. doi:10.1111/j.1474919X.2001.tb04176.x

Bro E, Mayot P, Corda E, Reitz F (2004) Impact of habitat management on grey partridge populations: assessing wildlife cover using a multisite BACI experiment. J Appl Ecol 41:846-857. doi:10.1111/j. 0021-8901.2004.00939.x

Bro E, Decors A, Millot F, Soyez D, Moinet M, Berny P, Mastain O (2010) Intoxications des perdrix grises en nature. Nouveau bilan de la surveillance « SAGIR ». Faune Sauvag 289:26-32. http:// www.oncfs.gouv.fr/IMG/file/suivi-sanitaire/FS289_bro.pdf. (in French)

Bro E, Millot F, Delorme R, Polvé C, Mangin E, Godard A, Tardif F, Gouache C, Sion I, Brault X, Durlin D, Gest D, Moret T, Tabourel R (2013) PeGASE, bilan synthétique d'une étude perdrix grise " population-environnement ». Faune Sauvag 298:17-48. http:// www.oncfs.gouv.fr/IMG/file/oiseaux/galliformes/pegase/FS298 bro_perdrix_grise_pegase.pdf. (in French)

Bro E, Millot F, Decors A, Devillers J (2015) Quantification of potential exposure of grey partridge (Perdix perdix) to pesticide active substances in farmlands. Sci Total Environ 521-522:315-325. doi:10. 1016/j.scitotenv.2015.03.073

Chamberlain DE, Fuller RJ, Bunces RGH, Duckworth JC, Shrubb M (2000) Changes in the abundance of farmland birds in relation to the timing of agricultural intensification in England and Wales. J Appl Ecol 37:771-788. doi:10.1046/j.1365-2664.2000.00548.x

Clark KE, Zhao Y, Kane CM (2009) Organochlorine pesticides, PCBs, dioxins, and metals in postterm peregrine falcon (Falco peregrinus) eggs from the Mid-Atlantic States, 1993-1999. Arch Environ Contam Toxicol 57:174-184. doi:10.1007/s00244-008-9248-9

COFRAC (2010) Guide technique d'accréditation - analyses de résidus de pesticides et de contaminants organiques dans les denrées alimentaires destinées à l'Homme ou aux animaux, les matrices biologiques d'origine animales. Document LAB GTA 26. Révision 00, 24p. https://www.cofrac.fr/documentation/LABGTA-26. (in French)

Comolet-Tirman J, Siblet J-P, Witté I, Cadiou B, Czajkowski M-A, Deceuninck B, Jiguet F, Landry P, Quaintenne G, Roché J-E, Sarasa, M, Touroult J (2015) Statuts et tendance des populations d'oiseaux nicheurs de France - Bilan simplifié du premier rapportage national au titre de la Directive Oiseaux. Alauda 83:35-76. http:// www.researchgate.net/publication/274705696_Statuts_et tendances_des_populations_d'oiseaux_nicheurs_de_France_bilan simplifi_du_premier_rapportage national_au titre $\overline{d e}$ la directive_oiseaux. (in French)

CSRPN (2013) Liste rouge des oiseaux nicheurs de la région Centre. $5 p$. http://www.centre.developpement-durable.gouv.fr/IMG/pdf/6oiseaux-nicheurs 2013 cle047818.pdf Connexion 6th July 2015

Donald PF, Green RE, Heath MF (2001) Agricultural intensification and the collapse of Europe's farmland bird populations. Proc Royal Soc London Ser B Biol Sci 268:25-29. doi:10.1098/rspb.2000.1325

Donald PF, Sanderson FJ, Burfield IJ, van Bommel FPJ (2006) Further evidence of continent-wide impacts of agricultural intensification on European farmland birds, 1990-2000. Agric Ecosyst Environ 116: 189-196. doi:10.1016/j.agee.2006.02.007

DRIAAF - Direction Régionale et Inter-régionale de l'Alimentation, de l'Agriculture et de la Forêt (2011) Actualités phytos Ile-de-France. $\mathrm{N}^{\circ} 16$, avril 2011, 5p. http://driaaf.ile-de-france.agriculture.gouv.fr/ IMG/pdf actualites phyto IDF 2011-04 cle8d8a96.pdf (in French)
Dunachie JF, Fletcher WW (1966) Effect of some insecticides on the hatching rate of hens' eggs. Nature 212:1062. doi:10.1038/ $2121062 \mathrm{a} 0$

Dunachie JF, Fletcher WW (1967) Effect of some herbicides on the hatching rate of hen's eggs. Nature 215:1406-1407. doi:10.1038/ $2151406 \mathrm{~b} 0$

Dunachie JF, Fletcher WW (1970) The toxicity of certain herbicides to hens' eggs assessed by the egg-injection technique. Annals Appl Biol 66:515-520. doi:10.1111/j.1744-7348.1970.tb04631.x

Egea-Serrano A, Relyea RA, Tejedo M, Torralva M (2012) Understanding of the impact of chemicals on amphibians: a metaanalytic review. Ecol Evol 2:1382-1397. doi:10.1002/ece3.249

Eglington SM, Pearce-Higgins JW (2012) Disentangling the relative importance of changes in climate and land-use intensity in driving recent bird population trends. PLoS ONE 7:e30407. doi:10.1371/ journal.pone. 0030407

Eng ML, Williams TD, Letcher RJ, Elliott JE (2014) Assessment of concentrations and effects of organohalogen contaminants in a terrestrial passerine, the European starling. Sci Total Environ 473-474: 589-596. doi:10.1016/j.scitotenv.2013.12.072

European Bird Census Council (2015) European wild bird indicators, 2015 update. http://www.ebcc.info/index.php?ID=588. Connexion 6th November 2015

EFSA - European Food Safety Authority (2009) Guidance document on risk assessment for birds and mammals on request from EFSA. EFSA J 7(12):1438. (revised July 2010) doi:10.2903/j.efsa.2009.1438

EFSA - European Food Safety Authority (2010) Conclusion on the peer review of the pesticide risk assessment of the active substance cyproconazole. EFSA J 8(11):1897,73p. doi:10.2903/j.efsa.2010.1897

EFSA - European Food Safety Authority (2011) Review of the existing maximum residue levels (MRLs) for tebuconazole according to Article 12 of Regulation (EC) No 396/2005. EFSA J 9(8):2339, 96p. doi:10.2903/j.efsa.2011.2339

EFSA - European Food Safety Authority (2014) Reasoned opinion on the review of the existing maximum residue levels (MRLs) for clothianidin and thiamethoxam according to Article 12 of Regulation (EC) No 396/2005. EFSA J 12(12):3918,120p. doi:10. 2903/j.efsa.2014.3918

European Commission (2011) EU biodiversity strategy to 2020. Publ Offic :60. doi:10.2779/39229

European Commision / Health \& Consumer Protection Directorate (2013) Guidance document on analytical quality control and validation procedures for pesticide residues analysis in food and feed. SANCO/12571/2013, implemented by $01 / 01 / 2014$. http://ec. europa.eu/food/plant/pesticides/guidance_documents/docs/ qualcontrol_en.pdf

Evans KL (2004) The potential for interactions between predation and habitat change to cause population declines of farmland birds. Ibis 146:1-13. doi:10.1111/j.1474-919X.2004.00231.x

Fernie K, Bortolottia G, Smitsa J (2003) Reproductive abnormalities, teratogenicity, and developmental problems in American Kestrels (Falco sparverius) exposed to polychlorinated biphenyls. J Toxicol Environ Health 66:2089-2103. doi:10.1080/ 15287390390211270

Fischer DL (2005) Accounting for differing exposure patterns between laboratory tests and the field in assessment of long-term risks of pesticides to terrestrial vertebrates. Ecotoxicology 14:853-862. doi:10.1007/s10646-005-0032-6

Fliedner A, Rüdel H, Jürling H, Müller J, Neugebauer F, SchröterKermani C (2012) Levels and trends of industrial chemicals (PCBs, PFCs, PBDEs) in archived herring gull eggs from German coastal regions. Environ Sci Eur 24:7. doi:10.1186/2190-4715-24-7

Fry M (1995) Reproductive effects in birds exposed to pesticides and industrial chemicals. Environ Health Perspect 103:165-171. http:// www.jstor.org/stable/3432528 
Gao F, Junluo X, Yang Z-F, Wang X-M, Mai B-X (2009) Brominated flame retardants, polychlorinated biphenyls, and organochlorine pesticides in bird eggs from the Yellow River Delta, North China. Environ Sci Technol 43:6956-6962. doi:10.1021/es901177j

Garg UK, Pal AK, Jha GJ, Jadhao SB (2004) Haemato-biochemical and immuno-pathophysiological effects of chronic toxicity with synthetic pyrethroid, organophosphate and chlorinated pesticides in broiler chicks. Intern Immunopharmacol 4:1709-1722. http://www.ncbi. nlm.nih.gov/pubmed/15454122

Geiger F, Bengtsson J, Berendse F et al. (2010) Persistent negative effects of pesticides on biodiversity and biological control potential on European farmland. Basic Appl Ecol 11:97-105. http://www. sciencedirect.com/science/article/pii/S1439179109001388

Gomez-Ramirez P, Martinez-Lopez E, Garcia-Fernandez AJ, Zweers AJ, van den Brink NW (2012) Organohalogen exposure in Eurasian Eagle Owl (Bubo bubo) population from Southeastern Spain: temporal trend and risk assessment. Chemosphere 88:903-911. http:// www.ncbi.nlm.nih.gov/pubmed/22503462

Gómez-Ramírez P, Shore RF, van den Brink NW, van Hattum B, Bustnes JO, Duke G, Fritsch C, García-Fernández AJ, Helander BO, Jaspers V, Krone O, Martínez-López E, Mateo R, Movalli P, Sonne C (2014) An overview of existing raptor contaminant monitoring activities in Europe. Environ Int 67:12-21. doi:10.1016/j.envint.2014.02.004

Hallmann CA, Foppen RP, van Turnhout CA, de Kroon H, Jongejans E (2014) Declines in insectivorous birds are associated with high neonicotinoid concentrations. Nature 511:341-343. doi:10.1038/ nature 13531

Hart JD, Milsom TP, Fisher G, Wilkins V, Moreby SJ, Murray AWA, Robertson PA (2006) The relationship between yellowhammer breeding performance, arthropod abundance and insecticide applications on arable farmland. J Appl Ecol 43:81-91. doi:10.1111/j. 1365-2664.2005.01103.x

Hoffman DJ, Albers PH (1984) Evaluation of potential embryotoxicity and teratogenicity of 42 herbicides, insecticides, and petroleum contaminants to mallard eggs. Arch Environ Contam Toxicol 13:15-27. http://ink.springer.com/article/10.1007\%2FBF01055642\#

Hoffman DJ, Rattner BA, Burton GA, Cairns J (2002) Handbook of ecotoxicology, 2nd edn. CRC Press, Boca Raton

Johnston G, Dawson A, Walker CH (1996) Effects of prochloraz and malathion on the red-legged partridge: a semi-natural field study. Environ Pollut 91:217-225. http://www.ncbi.nlm.nih.gov/pubmed/ 15091443

JMPR - Joint FAO/WHO Meeting on Pesticide Residues(2011) Pesticide residues in food 2010. Report of the Joint Meeting of the FAO Panel of Experts on Pesticide Residues in Food and the Environment and the WHO Core Assessment Group on Pesticide Residues. Rome, Italy, 21-30 September 2010. FAO Plant Prod Protect Pap 167: 590p. http://apps.who.int/pesticide-residues-jmpr-database/

Kamata R, Shiraishi F, Takahashi S, Shimizu A, Shiraishi H (2010) Reevaluation of the developmental toxicity of dieldrin by the use of fertilized Japanese quail eggs. Comparat Biochem Physiol 152: 84-90. http://www.ncbi.nlm.nih.gov/pubmed/20211759

Keller V, Gerber A, Schmid H, Volet B, Zbinden N (2010) Liste rouge oiseaux nicheurs. Espèces menacées en Suisse, état 2010. Office fédéral de l'environnement, Berne, et Station ornithologique suisse, Sempach. L'environnement Pratique $1019: 53 \mathrm{p}$. http://www.bafu. admin.ch/publikationen/publikation/01566/index.html?lang=fr (in French with an Engligh summary)

Kitulagodage M, Buttemer WA, Astheimer LB (2011) Adverse effects of fipronil on avian reproduction and development: maternal transfer of fipronil to eggs in zebra finch Taeniopygia guttata and in ovo exposure in chickens Gallus domesticus. Ecotoxicology 20:653-660. doi:10.1007/s10646-011-0605-5

Kocagöz R, Onmus O, Onat I, Cagdas B, Siki M, Orhan H (2014) Environmental and biological monitoring of persistent organic pollutants in waterbirds by non-invasive versus invasive sampling. Toxicol Lett 230:208-217. doi:10.1016/j.toxlet.2014.01.044

Köhler HR, Triebskorn R (2013) Wildlife ecotoxicology of pesticides: can we track effects to the population level and beyond? Science 341:759-765. doi:10.1126/science.1237591

Lopez-Antia A, Ortiz-Santaliestra ME, Mougeot F, Mateo R (2013) Experimental exposure of red-legged partridges (Alectoris rufa) to seeds coated with imidacloprid, thiram and difenoconazole. Ecotoxicology 22:125-138. doi:10.1007/s10646-012-1009-x

Lopez-Antia A, Ortiz-Santaliestra ME, García-de Blas E, Camarero PR, Mougeot F, Mateo R (2015) Adverse effects of thiram-treated seed ingestion on the reproductive performance and the offspring immune function of the red-legged partridge. Environ Toxicol Chem 34:1320-1329. doi:10.1002/etc. 2925

Ludwig JP, Kurita-Matsuba H, Auman HJ, Ludwig ME, Summer CL, Giesy JP, Tillitt DE, Jones PD (1996) Deformities, PCBs, and TCDD-equivalents in double-crested cormorants (Phalacrocorax auritus) and Caspian Terns (Hydroprogne caspia) of the Upper Great Lakes 1986-1991: testing a cause-effect hypothesis. J Great Lakes Res 22:172-197. doi:10.1016/S0380-1330(96)70948-6

Maci R, Arias E (1987) Teratogenic effects of the fungicide maneb on chick embryos. Ecotoxicol Environ Saf 13:169-173. http://www. ncbi.nlm.nih.gov/pubmed/3595485

Malik RN, Rauf S, Mohammad A, Eqani SA, Ahad K (2011) Organochlorine residual concentrations in cattle egret from the Punjab Province, Pakistan. Environ Monit Assess 173:325-341. doi:10.1007/s10661-010-1390-y

Marlière F (2009) Métrologie des polluants non règlementés Observation des niveaux de concentration en pesticides dans l'air ambiant (2/2). Laboratoire Central de Surveillance de la Qualité de l'Air, 65p. http://www.lesqa.org/polluants/polluants-nonreglementes. (in French)

Martínez-López E, María-Mojica P, Martínez JE, Calvo JF, Wright J, Shore RF (2007) Organochlorine residues in booted eagle (Hieraaetus pennatus) and goshawk (Accipiter gentilis) eggs from southeastern Spain. Environ Toxicol Chem 26:2373237-2373238. doi:10.1897/07-057R.1

McCabe RA, Hawkins AS (1946) The Hungarian partridge in Wisconsin. Am Midland Natural 36:1-75. http://www.jstor.org/stable/2421621

Meador JP (1996) Environmental contaminants in wildlife: interpreting tissue concentrations. CRC Press, Boca Raton

Mendenhall VM, Klaas EE, McLane MAR (1983) Breeding success of barn owls (Tyto alba) fed low levels of DDE and dieldrin. Arch Environ Contam. Toxicol 12:235-240. https://pubs.er.usgs.gov/ publication/5221837

Millot F, Berny P, Decors A, Bro E (2015) Little field evidence of direct acute and short-term effects of current pesticides on the grey partridge. Ecotoxicol Environ Saf 117:41-61. doi:10.1016/j.ecoenv. 2015.03.017

Mineau P (2005) A review and analysis of study endpoints relevant to the assessment of "long term" pesticide toxicity in avian and mammalian wildlife. Ecotoxicology 14:775-799. doi:10.1007/s10646-0050028-2

Mineau P, Whiteside M (2013) Pesticide acute toxicity is a better correlate of U.S. grassland bird declines than agricultural intensification. PLoS One 8:e57457.

Mourão JL, Barbosa AC, Outor-Monteiro D, Pinheiro VM (2010) Age affects the laying performance and egg hatchability of red-legged partridges (Alectoris rufa) in captivity. Poult Sci 89:2494-2498. doi: 10.3382/ps.2009-00377

Nakage ES, Cardozo JP, Pereira GT, Queiroz SA, Boleli IC (2003) Effect of temperature on incubation period, embryonic mortality, hatch rate, egg water loss and partridge chick weight (Rhynchotus rufescens). Rev Brasil Ciên Avícol 5:131-135. doi:10.1590/ S1516-635X2003000200007 
Nitu K, Shahani L, Taparia N, Bhatnagara P (2012) Teratogenic and biochemical effects of a formulation containing dicofol in the chick embryo. Toxicol Environ Chem 94:1411-1421. doi:10.1080/ 02772248.2012 .705287

Orton TG, Saby NP, Arrouays D, Jolivet CC, Villanneau EJ, Marchant BP, Caria G, Barrioso E, Bispo A, Briand O (2013) Spatial distribution of Lindane concentration in topsoil across France. Sci Total Environ 443:338-350. doi:10.1016/j.scitotenv.2012.10.103

Ottinger MA, Lavoie E, Thompson N, Barton A, Whitehouse K, Barton M, Abdelnabi QM Jr, Panzica G, Viglietti-Panzica C (2008) Neuroendocrine and behavioral effects of embryonic exposure to endocrine disrupting chemicals in birds. Brain Res Rev 57:376385, http://www.ncbi.nlm.nih.gov/pubmed/18006066

Quintaine T, Decors A, Bro E, Millot F, Aubry P (in press) Approche intégrée du suivi des effets non intentionnels aigus des produits phytopharmaceutiques sur la faune sauvage. Actes du $45^{\text {ème }}$ colloque du Groupe Français sur les Pesticides, 27-29 mai 2015, Versailles. http://www.gfpesticides.org/36-livre-d-actes-ducolloque-de-2015.html. (in French)

Rands MRW (1985) Pesticide use on cereals and the survival of grey partridge chicks: a field experiment. J Appl Ecol 22:49-54. http:// www.jstor.org/stable/2403325

Rivière J-L, Bach J, Grolleau G (1985) Effects of prochloraz on drug metabolism in the Japanese quail, grey partridge, chicken, and pheasant. Arch Environ Contam Toxicol 14:299-306. doi:10. 1007/BF01055406

Robinson RA, Sutherland WJ (2002) Post-war changes in arable farming and biodiversity in Great Britain. J Appl Ecol 39:157-176. doi:10. 1046/j.1365-2664.2002.00695.x

Sauveur B, de Reviers M (1988) Reproduction des volailles et production d'œufs. Editions Quae, Paris (in French)

Saxena AK, Devillers J, Bhunia SS, Bro E (2015) Modelling inhibition of avian aromatase by azole pesticides. SAR QSAR Environ Res 26: 757-782. doi:10.1080/1062936X.2015.1090749
Sotherton NW, Aebischer NJ, Ewald JA (2014) Research into action: grey partridge conservation as a case study. J Appl Ecol 51:1-5. doi:10.1111/1365-2664.12162

Stoate C, Báldi A, Beja P, Boatman ND, Herzon I, van Doorn A, de Snoo GR, Rakosy L, Ramwell C (2009) Ecological impacts of early 21 st century agricultural change in Europe: a review. J Environ Manag 91:22-46. doi:10.1016/j.jenvman.2009.07. 005

Uggini GK, Patel PV, Balakrishnan S (2012) Embryotoxic and teratogenic effects of pesticides in chick embryos: a comparative study using two commercial formulations. Environ Toxicol 27:166-174. doi:10. 1002/tox.20627

van der Sluijs JP, Amaral-Rogers V, Belzunces LP et al (2015) Conclusions of the worldwide integrated assessment on the risks of neonicotinoids and fipronil to biodiversity and ecosystem functioning. Environ Sci Pollut Res 22:148-154. doi:10.1007/s11356014-3229-5

van Lexmond BM, Bonmatin J-M, Goulson D, Noome DA (2015) Worldwide integrated assessment on systemic pesticides. Global collapse of the entomofauna: exploring the role of systemic insecticides. Environ Sci Pollut Res 22:1-4. doi:10.1007/s11356-0143220-1

Wiemeyer SN, Spann JW, Bunck CM, Krynitsky AJ (1989) Effects of Kelthane on reproduction of captive eastern screech-owls. Environ Toxicol Chem 8:903-913. doi:10.1002/etc.5620081009

Wiemeyer SN, Clark DR Jr, Spann JW, Belisle AA, Bunck CM (2001) Dicofol residues in eggs and carcasses of captive American kestrels. Environ Toxicol Chem 20:2848-2851. http://www.ncbi.nlm.nih. gov/pubmed/11764170

Wilson HR, Neuman SL, Eldred AR, Mather FB (2003) Embryonic malpositions in broiler Chickens and bobwhite quail. J Appl Poult Res 12:14-23. http://japr.oxfordjournals.org/content/12/1/14.full.pdf 